\title{
Acidosis and Lipopolysaccharide from Escherichia coli B:055 Cause Hyperpermeability of Rumen and Colon Tissues
}

\author{
D. G. V. Emmanuel, ${ }^{*}$ K. L. Madsen,† T. A. Churchill,ł S. M. Dunn, ${ }^{*}$ and B. N. Ametaj ${ }^{* 1}$ \\ *Department of Agricultural, Food and Nutritional Science, University of Alberta, Edmonton, Alberta T6G 2P5, Canada \\ †Department of Medicine, Division of Gastroenterology, University of Alberta, Edmonton, Alberta T6G 2C8, Canada \\ $\ddagger$ Surgical Medical Research Institute, University of Alberta, Edmonton, Alberta T6G 2N8, Canada
}

\begin{abstract}
The objective of the present investigation was to evaluate the effects of acidic $\mathrm{pH}$ of the perfusate and presence of lipopolysaccharide (LPS) on permeability of rumen and colon mucosal tissues to mannitol and LPS using the Ussing chamber system. Rumen and colon tissues $(n=8)$, obtained from slaughtered feedlot steers, were tested for changes in permeability to ${ }^{3} \mathrm{H}$-mannitol under $\mathrm{pH}$ of $4.5,5.5$, and 6.5 for rumen and at 5.5, 6.5, and 7.4 for colon, with or without LPS from Escherichia coli B:055 at $500 \mu \mathrm{g} / \mathrm{mL}$. The ${ }^{3} \mathrm{H}-\mathrm{Mannitol}$ was added at $10 \mu \mathrm{L}(525.4 \mathrm{GBq} / \mathrm{mmol})$ on the mucosal side of the Ussing chamber to detect changes in permeability, and 4 samples were taken at 20,25, 30, and $35 \mathrm{~min}$ from the serosal side. Permeability of rumen and colon mucosa to ${ }^{3} \mathrm{H}$-mannitol increased 6- and 5-fold, respectively, at acidic $\mathrm{pH}$ values of 4.5 and 5.5 and in the presence of $500 \mu \mathrm{g} / \mathrm{mL}$ of LPS. In contrast, LPS did not affect rumen and colon permeability at $\mathrm{pH}$ that ranged from 5.5 and 7.4. Translocation of LPS across the rumen and colon mucosa of cattle was not $\mathrm{pH}$ dependent. The LPS translocated through these tissues if present at the mucosal side. In conclusion, the permeability of rumen and colon tissues to ${ }^{3} \mathrm{H}$-mannitol increased in presence of LPS and under acidic $\mathrm{pH}$, whereas LPS permeated through mucosal tissues independently of the $\mathrm{pH}$ of the perfusate. Further research is warranted to understand the mechanism(s) by which acidic $\mathrm{pH}$ of the rumen digesta and presence of LPS make rumen and colon tissues "leaky".
\end{abstract}

Key words: cattle, acidosis, lipopolysaccharide, mucosal permeability

\section{INTRODUCTION}

Feeding dairy cows diets containing high proportions of grain is associated with a rapid decline in ruminal

Received April 4, 2007.

Accepted September 5, 2007.

${ }^{1}$ Corresponding author: burim.ametaj@ualberta.ca
$\mathrm{pH}$ (i.e., acidosis) as well as alterations in the microbial ecology (Keunen et al., 2002). Based on the degree and the length of time at which ruminal $\mathrm{pH}$ remains below a certain threshold, 2 conditions are identified in dairy cows as acute or subacute ruminal acidosis (ARA or SARA, respectively). The critical thresholds for diagnosis of ARA or SARA are defined as ruminal $\mathrm{pH}$ values of $<5.0$ or $<5.6$, respectively (Nagaraja and Town, 1990). Cows affected by acute ruminal acidosis develop symptoms that include decreased DMI, loss of BW, diarrhea, and lameness (Nocek, 1997). Other events associated with SARA or ARA are decreased ruminal motility, stasis, rumenitis, and hyperkeratosis (Dirksen et al., 1984). The mechanism(s) by which rumen acidosis affects general health and performance of cows is not clear; however, rapid fermentation of starch and the release of vast amounts of VFA and lactic acid have been implicated in development of clinical pathology.

Feeding cattle high-grain diets is also associated with 18- to 20-fold increase in the amount of endotoxin in the rumen fluid (Nagaraja et al., 1978a). There are indications that endotoxin translocates into the bloodstream and causes a variety of metabolic and immunologic alterations to the host (Andersen et al., 1994). Moreover, endotoxin plays a role in several metabolic disorders in cattle such as laminitis, abomasal displacement, fatty liver, and sudden death syndrome (Ametaj et al., 2005). The precise mechanism(s) and the favorable conditions that facilitate translocation of endotoxin into the blood circulation are not known, and attempts to measure endotoxin in the systemic circulation have not been very fruitful (Andersen et al., 1994; Gozho et al., 2007).

Because acidic environments and the presence of endotoxin render the mucosal epithelium more permeable and susceptible to apoptosis (Chin et al., 2006), we hypothesized that exposing rumen and colon tissues of cattle to acidotic $\mathrm{pH}$ and LPS will alter their permeability and lead to translocation of LPS through these tissues. To test our hypothesis we conducted an in vitro experiment in an Ussing chamber system. 
Table 1. Reagents ${ }^{1}$ and final concentration in the amino acid solution

\begin{tabular}{lcc}
\hline Reagent & $\begin{array}{c}\text { Final } \\
\text { concentration } \\
(\mathrm{mmol})\end{array}$ & $\begin{array}{c}\text { Quantity } \\
(\mathrm{g} / \mathrm{L})\end{array}$ \\
\hline Lactobionate & 20 & 7.1660 \\
Glutamate & 20 & 2.9420 \\
Aspartic acid & 20 & 2.6620 \\
Arginine & 10 & 1.7420 \\
Proline & 5 & 0.5755 \\
Glycine & 10 & 0.7507 \\
Cysteine & 5 & 0.6060 \\
Asparagine & 10 & 1.5010 \\
Threonine & 10 & 1.1910 \\
Lysine & 10 & 1.8260 \\
Methionine & 5 & 0.7460 \\
Serine & 10 & 1.0510 \\
Leucine & 5 & 0.6560 \\
Isoleucine & 5 & 0.6560 \\
Valine & 10 & 1.1710 \\
Histidine & 5 & 0.7760 \\
Tyrosine & 1 & 0.1812 \\
Tryptophan & 1 & 0.2042 \\
Ornithine & 5 & 0.8430 \\
Trolox & 1 & 0.2500 \\
3-Aminobenzamide & 1 & 0.1360 \\
HO-butyrate & 3 & 0.3783 \\
Glucose & 20 & 3.6040 \\
N,N-Bis(2-hydroxyethyl)taurine & 15 & 3.1980 \\
Glutamine & 35 & 5.1130 \\
Adenosine & 5 & 1.3360 \\
Allopurinol & 1 & 0.1361 \\
Hydroxyethil starch & $5 \mathrm{~g} / \mathrm{dL}$ & 50.0000 \\
\hline 1-The & $5 H$ & \\
\hline
\end{tabular}

${ }^{1}$ The $\mathrm{pH}$ of the solution was adjusted to $7.40 \pm 0.01$ using $2 \mathrm{M}$ $\mathrm{NaOH}$.

\section{MATERIALS AND METHODS}

\section{Animals and Treatments}

Sample Collection and Preparation. Rumen and colon samples for the experiment were collected from an Edmonton-based abattoir (Edmonton Custom Packers, Edmonton, Alberta, Canada). Colon samples were selected for the experiment because a large number of gram-negative bacteria and especially Escherichia coli harbor that section of the gastrointestinal tract of ruminant animals (Grauke et al., 2002). Within 10 min after slaughter of healthy feedlot steers $(\mathrm{n}=16)$, a $15-\mathrm{cm}^{2}$ area of rumen tissue or a $15-\mathrm{cm}$ length of colon were excised from the gastrointestinal tract of each animal, washed with cold Ringer's lactate (Sigma-Aldrich Canada Ltd., Oakville, Ontario, Canada) solution, and stored in an enriched amino acid solution (Salehi et al., 2007) until processing and mounting the tissues in the Ussing chamber. Composition of the amino acid solution and Ringer's lactate are given in Tables 1 and 2 , respectively. The amino acid-based solution is an intestinal-specific preservation solution developed experimentally for the cold storage of intestine (Salehi et al., 2007). Samples were carried to the laboratory in the cold amino acid solution $\left(4\right.$ to $\left.-5^{\circ} \mathrm{C}\right)$ in a cooler and
Table 2. Reagents ${ }^{1}$ and their final concentrations in Ringer's lactate solution

\begin{tabular}{|c|c|c|}
\hline Compound & $\begin{array}{c}\text { Final } \\
\text { concentration } \\
(\mathrm{mmol})\end{array}$ & $\begin{array}{l}\text { Quantity } \\
\text { (g/2 L) }\end{array}$ \\
\hline $\mathrm{MgCl}_{2} \cdot 6 \mathrm{H}_{2} \mathrm{O}$ & 114.00 & 0.447 \\
\hline $\mathrm{CaCl}_{2} \cdot 2 \mathrm{H}_{2} \mathrm{O}$ & 5.00 & 0.367 \\
\hline $\mathrm{NaCl}$ & 1.65 & 13.320 \\
\hline $\mathrm{KCl}$ & 0.30 & 0.750 \\
\hline $\mathrm{NaHCO}_{3}$ & 1.10 & 4.200 \\
\hline $\mathrm{Na}_{2} \mathrm{HPO}_{4}$ & 1.25 & 0.468 \\
\hline $\mathrm{NaH}_{2} \mathrm{PO}_{4} \cdot 2 \mathrm{H}_{2} \mathrm{O}$ & 25.00 & 0.094 \\
\hline${ }^{3} \mathrm{H}-$ Mannitol & 1.00 & 0.364 \\
\hline
\end{tabular}

${ }^{1}$ The reagents were added in the order listed and brought to final volume with doubly distilled $\mathrm{H}_{2} \mathrm{O}$ and $\mathrm{pH} 7.4$ using $\mathrm{HCl}$ or $\mathrm{NaOH}$.

during transportation the samples were aerated with a syringe to facilitate respiration of the tissues. On reaching the laboratory, samples were prepared for mounting in an Ussing chamber on a glass surface which was kept cold by ice underneath. The serosal and muscular layers were peeled off carefully from both rumen and colon samples, and the maximum possible fibrous tissue was removed from the mucosa without injuring the tissue. Rumen $(\mathrm{n}=8)$ and colon $(\mathrm{n}=8)$ samples were collected from 16 different animals. One rumen or 1 colon sample was run on a certain day. The rumen or colon tissue was cut into 6 squares (approximately $2 \mathrm{~cm}^{2}$ ) for mounting in 6 different Ussing chambers ( 3 control and 3 treatments) exposing an area of $1.76 \mathrm{~cm}^{2}$. The time from collection to mounting of tissues in the chambers was approximately $40 \mathrm{~min}$.

Ussing Chamber Experiment. After turning on the water heater and assembling the lucite chambers between the supporting screws, $10 \mathrm{~mL}$ of Ringer's lactate at $\mathrm{pH} 7.4$ was added to both reservoirs of the Ussing chamber. The quantity of each reagent for preparation of Ringer's lactate is shown in Table 2. Any air bubbles in the lucite chamber were removed by adjusting the leads. To both reservoirs of Ussing chamber, $200 \mu \mathrm{L}$ of a 1-mmol glucose solution was added and chambers were connected to a $95 \% \mathrm{O}_{2} / 5 \% \mathrm{CO}_{2}$ airlift. Once the Ringer's lactate in the system attained a temperature of $39^{\circ} \mathrm{C}$, the resistance button was adjusted to bring the fluid resistance to zero. The instrument was then switched to standby and the tubular ends of the lucite chambers were clamped on both the serosal and the mucosal reservoirs, and the right half of the chamber was removed. The prepared colon or rumen tissue was mounted on the pins of the chamber with the mucosal side in contact with the left lucite chamber and the chambers were then reassembled. Once the rumen or colon tissues were mounted on all the 6 Ussing chambers ( 3 controls and 3 treatments), the Ringer's lactate in the mucosal side of the chamber was drained and 
replaced with Ringer's lactate and $\mathrm{pH}$ was adjusted to $4.5,5.5$, or 6.5 for rumen samples and 5.5, 6.5, and 7.4 for colon samples. After adjusting the $\mathrm{pH}, 10 \mu \mathrm{L}$ of ${ }^{3} \mathrm{H}$ mannitol (525.4 GBq/mmol; PerkinElmer, Woodbridge, Ontario, Canada) and $500 \mu \mathrm{g} / \mathrm{mL}$ of LPS from $E$. coli B:055 (Sigma-Aldrich Canada Ltd.) were added to the solution on the mucosal side of the chambers, on the treatment samples, to evaluate permeability to ${ }^{3} \mathrm{H}$ mannitol and LPS. The amount of LPS used was chosen based on the amount of endotoxin in the rumen fluid of cattle fed all-grain diets ( 86 to $860 \mu \mathrm{g} / \mathrm{mL}$ of LPS; Nagaraja et al., 1978b). The system was allowed to equilibrate for $15 \mathrm{~min}$, and at $15 \mathrm{~min} 2$ samples (radioactive; $100 \mu \mathrm{L}$ each) were taken from the mucosal side of the chambers to detect the initial concentration of ${ }^{3} \mathrm{H}$-mannitol. At time 20, 25, 30, and $35 \mathrm{~min}, 1-\mathrm{mL}$ and $200-\mu \mathrm{L}$ samples (nonradioactive) were taken separately from the serosal compartment for detection of ${ }^{3} \mathrm{H}$-labeled mannitol and LPS. At the end of $40 \mathrm{~min}$, another 2 fluxes ( $100 \mu \mathrm{L}$ each) were taken from the mucosal side of the chambers to detect the available concentration of ${ }^{3} \mathrm{H}$-mannitol in the mucosal side after translocation into the serosal side. Although multiple samples were obtained at different time points, results presented are the average of all time points. After each sampling, measurements were made to determine the isoelectric current and the potential difference.

\section{Determination of ${ }^{3} \mathrm{H}$-Mannitol}

Four milliliters of scintillation fluid was added to the vials for detection of ${ }^{3} \mathrm{H}$-mannitol. The amount of radiation was measured as counts per minute in a liquid scintillation counter (Beckman Instruments, Irvine, $\mathrm{CA}$ ). The quantity of translocated ${ }^{3} \mathrm{H}$-mannitol was calculated from the difference between the counts per minute of radioactive and nonradioactive fluxes.

\section{Determination of LPS}

Lipopolysaccharide from $E$. coli B:055 in the serosal side of the chamber was quantified indirectly by determining the amounts of $\mathrm{C}_{12}$-lauric and $\mathrm{C}_{14}$-myristic fatty acids in the solution (Silipo et al., 2002). The fatty acid composition of LPS from $E$. coli is described by Datta and Basu (1999). For measurement of LPS, 100 $\mu \mathrm{L}$ of the sample was freeze-dried. The freeze-dried samples were methylated by adding $1,000 \mu \mathrm{L}$ of methanolic HCl $3 N$ (Supelco, Bellefonte, PA). The samples were then vortexed before placing them in a water bath at $50^{\circ} \mathrm{C}$ and shaken every $5 \mathrm{~min}$ for $30 \mathrm{~min}$. Methylated fatty acids were extracted by adding $50 \mu \mathrm{L}$ of $\mathrm{H}_{2} \mathrm{O}$ and $3 \mathrm{~mL}$ of hexane and shaking vigorously for $20 \mathrm{~s}$. The top hexane portion was then removed using a disposable
Pasteur pipette (Fisher Scientific, Fair Lawn, NJ) and dried under liquid nitrogen. The dried fatty acids were again dissolved in $150 \mu \mathrm{L}$ of hexane containing internal standard ( $2 \mathrm{mg} \mathrm{C}_{17}$ in $1,000 \mu \mathrm{L}$ of hexane) and injected into $50 \mathrm{~mm} \times 0.25 \mathrm{~mm}$ film thickness capillary column (Supelco) in a Varian 3400 gas chromatography equipped with Varian 8100 autosampler (Varian, Canada, Inc. Mississauga, Ontario, Canada). Helium was used as the carrier gas at a rate of $1.5 \mathrm{~mL} / \mathrm{min}$. Injector temperature was programmed from $50^{\circ} \mathrm{C}$ to $230^{\circ} \mathrm{C}$ at $150^{\circ} \mathrm{C} / \mathrm{min}$ with a run time of $36 \mathrm{~min}$. Detector temperature was set at $230^{\circ} \mathrm{C}$, and peak area integration for fatty acids were made using Galaxy software (Varian Inc., Walnut Creek, CA).

\section{Statistical Analyses}

Data were subjected to statistical analysis by MIXED procedure of SAS Institute Inc. (1989) to determine the effects of presence of LPS and acidic $\mathrm{pH}$ on permeability to ${ }^{3} \mathrm{H}$-mannitol and translocation of LPS through rumen and colon tissues, using the following model:

$$
\mathrm{Y}_{i j k}=\mu+\mathrm{T}_{i}+\mathrm{P}_{j}+\mathrm{TP}_{i j}+\mathrm{A}_{\mathrm{k}}+e_{i j k},
$$

where $\mu$ is the population mean; $T_{i}$ is the fixed effect of treatment $i$ where $i=1,2$; and $\mathrm{P}_{j}$ is the fixed effect of $\mathrm{pH} j$ where $j=1,2$, and $3 ; \mathrm{TP}_{i j}$ is the effect of treatment $\times \mathrm{pH}$ interaction; $\mathrm{A}_{\mathrm{k}}$ is the random effect of sample $k$ where $k=1$ to 8 ; and $e_{i j k}$ is the residual error. The PDIFF option was used in each of the comparisons. Significance was declared at $P<0.05$.

\section{RESULTS}

\section{Permeability of Rumen and Colon Tissues to ${ }^{3} \mathrm{H}$-Mannitol}

Acidic $\mathrm{pH}$ with the presence of LPS increased permeability of rumen tissue to ${ }^{3} \mathrm{H}$-mannitol $(P<0.05$; Figure 1). Presence of LPS increased permeability of rumen tissue to ${ }^{3} \mathrm{H}$-mannitol with a permeability of $11.7 \mathrm{nmol} /$ $\mathrm{cm}^{2} / \mathrm{h}$ compared with $4.9 \mathrm{nmol} / \mathrm{cm}^{2} / \mathrm{h}$ in the controls. An interaction between LPS and $\mathrm{pH}$ was obtained with respect to permeability of rumen tissue to ${ }^{3} \mathrm{H}$-mannitol $(P<0.05)$ at the lowest $\mathrm{pH}$ value of the perfusate. Permeability increased by more than 6 -fold at a $\mathrm{pH}$ of 4.5 in the presence of LPS $\left(4.10 \mathrm{vs} .25 .09 \mathrm{nmol} / \mathrm{cm}^{2} / \mathrm{h}\right)$. But, presence of LPS did not affect permeability of rumen tissue to ${ }^{3} \mathrm{H}$-mannitol at $\mathrm{pH}$ values of 5.5 and 6.5.

At $\mathrm{pH} 5.5$ in the presence of LPS there was increased permeability of colon tissues to ${ }^{3} \mathrm{H}$ - mannitol (Figure 2; $P<0.05$ ). The interaction between $\mathrm{pH}$ and LPS was evident, with increased permeability to ${ }^{3} \mathrm{H}$-mannitol at the lowest $\mathrm{pH}$ value $(P<0.01)$. At $\mathrm{pH}$ values of 5.5 , the 


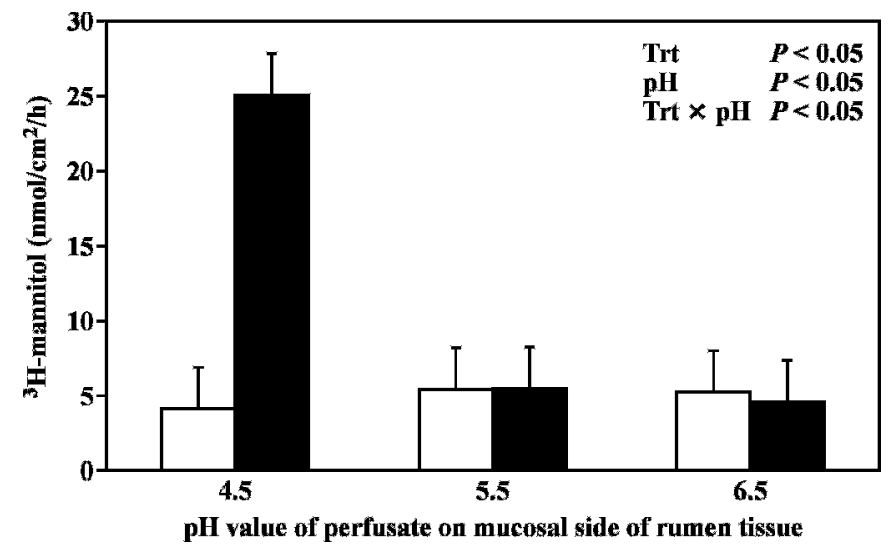

Figure 1. Permeability of rumen tissue obtained from steers to ${ }^{3} \mathrm{H}$-mannitol under different $\mathrm{pH}$ and in presence (ם) or absence ( $\square$ ) of LPS from Escherichia coli B:055 in an Ussing chamber (Trt = treatment; $\mathrm{pH}=\mathrm{pH}$ value of perfusate; Trt $\times \mathrm{pH}=$ treatment by $\mathrm{pH}$ interaction).

permeability of the colon to ${ }^{3} \mathrm{H}$-mannitol in the control and the LPS-treated groups was different (137.01 vs. $\left.29.1 \mathrm{nmol} / \mathrm{cm}^{2} / \mathrm{h} ; P<0.05\right)$, whereas there were no differences due to LPS at $\mathrm{pH}$ of 6.5 and 7.4.

\section{Permeability of Rumen and Colon Tissues to LPS}

There was translocation of LPS from the mucosal to the serosal side of the Ussing chamber in all rumen tissues treated with LPS $(P<0.01)$. The amount of LPS that went through the rumen tissue at $\mathrm{pH} 4.5,5.5$, and 6.5 was 361,431 , and $312 \mathrm{nmol} / \mathrm{cm}^{2} / \mathrm{h}$ for treatments vs. 0,24 , and $6.5 \mathrm{nmol} / \mathrm{cm}^{2} / \mathrm{h}$ for controls, respectively. Still, exposure of rumen tissues to different acidic $\mathrm{pH}$

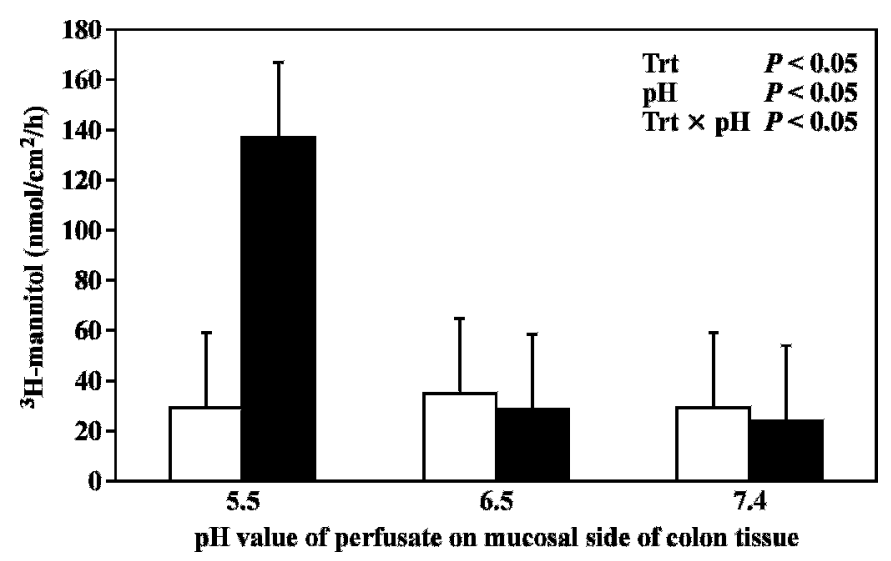

Figure 2. Permeability of colon tissue obtained from steers to ${ }^{3} \mathrm{H}$ mannitol under different $\mathrm{pH}$ and in presence ( $\square$ ) or absence ( $\square$ ) of LPS from Escherichia coli B:055 in an Ussing chamber (Trt = treatment; $\mathrm{pH}=\mathrm{pH}$ value of perfusate; $\operatorname{Trt} \times \mathrm{pH}=$ treatment by $\mathrm{pH}$ interaction).

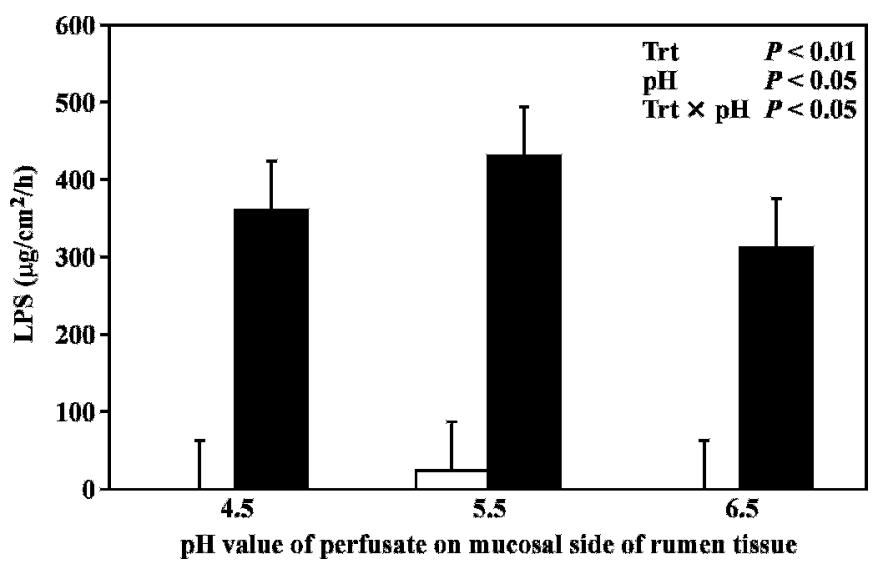

Figure 3. Translocation of LPS from Escherichia coli B:055 across rumen tissue obtained from steers under different $\mathrm{pH}$ values and in presence ( $\square$ ) or absence ( $\square$ ) of LPS from E. coli B:055 in the mucosal reservoir of Ussing chamber $(\mathrm{Trt}=$ treatment; $\mathrm{pH}=\mathrm{pH}$ value of perfusate; $\operatorname{Trt} \times \mathrm{pH}=$ treatment by $\mathrm{pH}$ interaction).

did not affect translocation of LPS and there was no difference in the quantity of LPS translocated between the different $\mathrm{pH}$ groups (Figure 3). Furthermore, no interaction $(P>0.05)$ between $\mathrm{pH}$ and LPS was obtained. Evidently, LPS was translocated from the mucosal to the serosal side of the Ussing chamber at all 3 $\mathrm{pH}$ values when the colon tissues were exposed to LPS $(P<0.01$; Figure 4$)$. Thus, the amount of LPS that permeated through the colon tissues at $\mathrm{pH} 5.5,6.5$, and 7.4 was 149,219 , and $167 \mathrm{nmol} / \mathrm{cm}^{2} / \mathrm{h}$ in treatments vs. 0,24 , and $0 \mathrm{nmol} / \mathrm{cm}^{2} / \mathrm{h}$ in controls, respectively. All 3 $\mathrm{pH}$ values did not affect translocation of LPS through the colon tissues, and no interaction $(P>0.05)$ between $\mathrm{pH}$ and LPS was obtained.

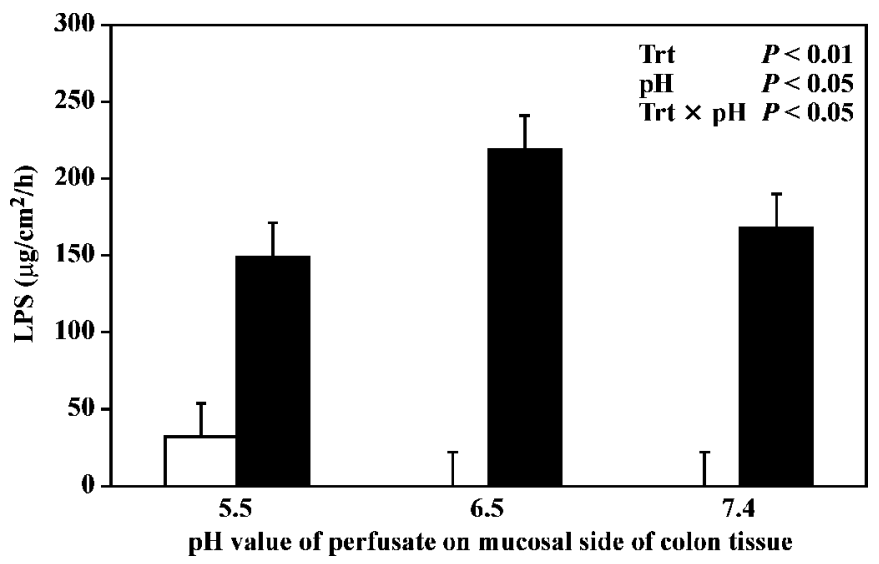

Figure 4. Translocation of LPS from Escherichia coli B:055 across colon tissue obtained from steers under different $\mathrm{pH}$ values and in presence ( $\square$ ) or absence ( $\square$ ) of LPS from E. coli B:055 in the mucosal reservoir of Ussing chamber $($ Trt $=$ treatment; $\mathrm{pH}=\mathrm{pH}$ value of perfusate; $\operatorname{Trt} \times \mathrm{pH}=$ treatment by $\mathrm{pH}$ interaction). 


\section{DISCUSSION}

The most important finding of this study was that in presence of LPS at acidic $\mathrm{pH}$ values of the perfusate similar with ARA (i.e., $\mathrm{pH} 4.5$ and 5.5 for rumen and colon, respectively) there was an increase of more than 6 -fold and 5-fold in the permeability of rumen and colon tissues, respectively, to ${ }^{3} \mathrm{H}$-mannitol. Conversely, $\mathrm{pH}$ values similar with SARA and normal $\mathrm{pH}$ values of the perfusate did not affect permeability of rumen and colon mucosal tissues to ${ }^{3} \mathrm{H}$-mannitol. Whereas LPS and acidic $\mathrm{pH}$ are known to increase the permeability of the mucosa separately (Chin et al., 2006), the increased permeability observed in our study at both acidic $\mathrm{pH}$ of the perfusate and presence of LPS suggests that the 2 factors combine to further enhance the permeability of mucosa to ${ }^{3} \mathrm{H}$-mannitol. Tests of gastrointestinal tissue permeability to low molecular weight carbohydrates like mannitol have a considerable application in the study of gastrointestinal pathologies. Mannitol is a nonmetabolizable sugar with a molecular weight of $182 \mathrm{Da}$ and diameter of $0.67 \mathrm{~nm}$. Normally, mannitol crosses the epithelial layers through water-filled pores and is commonly used as an intestinal permeability probe (Hollander et al., 1988). Changes in the integrity of the epithelial tissues are associated with enhanced permeability to mannitol. Therefore, increased permeability to ${ }^{3} \mathrm{H}$-mannitol in our experimental conditions involving low acidic $\mathrm{pH}$ plus LPS suggest alterations in the integrity of the mucosal layers during ARA in cattle.

Although the mechanism(s) by which low $\mathrm{pH}$ and presence of LPS enhanced permeability of rumen and colon tissues to ${ }^{3} \mathrm{H}$-mannitol is not clear; studies examining the effects of acidic $\mathrm{pH}$ on mucosal permeability reveal that acidic environments affect the permeability of mucosal epithelial layers by increasing production of NO in enterocytes (Unno et al., 1997). Also, LPS induced production of $\mathrm{NO}$ in various enterocytic cell lines in vitro (Dignass et al., 1995). Presence of high concentrations of NO may inhibit production of ATP and damage enterocytes (Unno et al., 1997). Our data, with rumen and colon tissues, indicated that lowering the $\mathrm{pH}$ in presence of LPS increased the permeability to ${ }^{3} \mathrm{H}$ mannitol. The increased permeability at a $\mathrm{pH}$ of 4.5 for rumen and a $\mathrm{pH}$ of 5.5 for colon tissues, in presence of LPS, may be due to combined disrupting effects of LPS and acidic $\mathrm{pH}$ on the epithelial barrier functions.

Another significant finding of the present study was that translocation of LPS across the rumen and colon mucosa was not $\mathrm{pH}$ dependent. Lipopolysaccharide permeated through these tissues at the rates presented in Figures 3 and 4 and at concentrations used in our study (i.e., $500 \mu \mathrm{g} / \mathrm{mL}$ ). A small amount of LPS permeated through the rumen and colon mucosal tissues in the control chambers. Although no LPS was added in those chambers it is possible that bacteria attached to the mucosal layers contributed the small amounts of LPS measured. Results of this study confirm previous research conducted by Drewe et al. (2001) indicating that translocation of LPS through mucosal layers is not dependent on $\mathrm{pH}$ ( $\mathrm{pH} 6.0$ to 8.0). It's not clear how LPS permeates through mucosal tissues; however, Drewe et al. (2001) demonstrated that translocation of LPS can take place both by simple diffusion through transcellular pathways as well as by paracellular pathway and that translocation was not related to the presence of $\mathrm{Na}^{+}$ions. The latter indicates that no $\mathrm{Na}^{+}$-pumps (i.e., active transport) are involved in transportation of LPS.

Our finding that LPS translocated if present at high concentrations in the gut is reinforced by several other studies. For example, enteral administration of endotoxin in mice resulted in elevation of concentration of endotoxin in blood compared with control mice (Schwarzenberg and Bundy, 1994). In vitro studies with isolated gut segments demonstrated that the flux of LPS was not proportional to concentration of LPS present in the mucosal side, but rather the transport system attained a saturated state with a threshold concentration (Nolan et al., 1977). It is possible that concentration of LPS, which we used in the present study $(500 \mu \mathrm{g} /$ $\mathrm{mL}$ ), was sufficient to disrupt the mucosal barrier functions and result in translocation of LPS to the serosal side.

Overall, results of this study suggest that under acidic $\mathrm{pH}$ and high concentrations of endotoxin in the rumen or colon, as reported during feeding of cattle high-grain diets, there is translocation of endotoxin and alteration of the permeability of mucosal tissues. Further research is warranted to understand the pathway that endotoxin follows after translocation into the serosal side as well as the mechanism(s) by which acidic $\mathrm{pH}$ and presence of LPS make rumen and colon tissues "leaky".

\section{CONCLUSIONS}

In conclusion, the permeability of rumen and colon tissues to ${ }^{3} \mathrm{H}$-mannitol increased 6- and 5 -fold, respectively, in presence of LPS from $E$. coli B:055 and acidic $\mathrm{pH}$ of $\mathrm{pH} 4.5$ and 5.5, respectively. No translocation of ${ }^{3} \mathrm{H}$-mannitol occurred when the $\mathrm{pH}$ on the mucosal side was at $\mathrm{pH} 5.5$ and 6.5 for rumen tissues and $\mathrm{pH} 6.5$ and 7.4 for colon tissues. Translocation of LPS occurred across the rumen and colon tissues independently of all $\mathrm{pH}$ values tested.

\section{ACKNOWLEDGMENTS}

We gratefully acknowledge the financial contribution of the Natural Sciences and Engineering Research 
Council of Canada and University of Alberta. We are thankful to the technical help provided by Kelvin Lien with the gas chromatography, Andrea Dmytrash with the Ussing chamber, and Geneva Hurd (Univ. Alberta, Edmonton) with preparation of amino acid solutions. The authors also thank the technical staff at Edmonton Custom Packers for providing rumen and colon tissues and acknowledge the statistical advice by Laki Goonewardene (Univ. Alberta, Edmonton).

\section{REFERENCES}

Ametaj, B. N., B. J. Bradford, G. Bobe, R. A. Nafikov, Y. Lu, J. W. Young, and D. C. Beitz. 2005. Strong relationship between mediators of the acute phase response and fatty liver in dairy cows. Can. J. Anim. Sci. 85:165-175.

Andersen, P. H., M. Hesselholt, and N. Jarlov. 1994. Endotoxin and arachidonic acid metabolites in portal, hepatic and arterial blood of cattle with acute ruminal acidosis. Acta Vet. Scand. 35:223234.

Chin, A. C., A. N. Flynn, J. P. Fedwick, and A. G. Buret. 2006. The role of caspase-3 in lipopolysaccharide-mediated disruption of intestinal epithelial tight junctions. Can. J. Physiol. Pharmacol. 84:1043-1050.

Datta, A. K., and S. Basu. 1999. Chemical characterization of the lipopolysaccharides from enteropathogenic Escherichia coli $\mathrm{O} 142$ and O158. Indian J. Biochem. Biophys. 36:55-58.

Dignass, A. U., D. K. Podolsky, and D. Rachmilewitz. 1995. $\mathrm{NO}_{2}$ generation by cultured small intestinal epithelial cells. Dig. Dis. Sci. 40:1859-1865.

Dirksen, V. G., H. G. Liebich, G. Brosi, H. Hagemeister, and E. Mayer. 1984. Morphology of the rumen mucosa and fatty acid absorption in cattle-Important factors for health and production. Zentralbl. Veterinaermed. 31:414-430.

Drewe, J., C. Beglinger, and G. Fricker. 2001. Effect of ischemia on intestinal permeability of lipopolysaccharides. Eur. J. Clin. Invest. 31:138-144.

Gozho, G. N., D. O. Krause, and J. C. Plaizier. 2007. Ruminal lipopolysaccharide concentration and inflammatory response during grain-induced subacute ruminal acidosis in dairy cows. J. Dairy Sci. 90:856-866.
Grauke, L. J., I. T. Kudva, J. W. Yoon, C. W. Hunt, C. J. Williams, and C. J. Hovde. 2002. Gastrointestinal tract location of Escherichia coli O157:H7 in ruminants. Appl. Environ. Microbiol. 68:2269-2277.

Hollander, D., D. Ricketts, and C. A. R. Boyd. 1988. Importance of "probe" molecular geometry in determining intestinal permeability. Can. J. Gastroenterol. 2:35-38.

Keunen, J. E., J. C. Plaizier, L. Kyriazakis, T. F. Duffield, T. M. Widowski, M. I. Lindinger, and B. W. McBride. 2002. Effects of a subacute ruminal acidosis model on the diet selection of dairy cows. J. Dairy Sci. 85:3304-3313.

Nagaraja, T. G., E. E. Bartley, L. R. Fina, and H. D. Anthony. 1978a. Relationship of rumen gram-negative bacteria and free endotoxin to lactic acidosis in cattle. J. Anim. Sci. 47:1329-1336.

Nagaraja, T. G., E. E. Bartley, L. R. Fina, H. D. Anthony, and R. M. Bechtle. 1978b. Evidence of endotoxins in the rumen bacteria of cattle fed hay or grain. J. Anim. Sci. 47:226-234.

Nagaraja, T. G., and G. Town. 1990. Ciliated protozoa in relation to ruminal acidosis and lactic acid metabolism. Page 187-194 in Rumen Ecosystem: Microbial Metabolism and Regulation. R. Oneora, H. Minato, and H. Itabashi, ed. Springer-Verlag, New York, NY.

Nocek, J. E. 1997. Bovine acidosis: Implications on laminitis. J. Dairy Sci. 80:1005-1028.

Nolan, J. P., D. K. Hare, J. J. McDevitt, and M. V. Ali. 1977. In vitro studies of intestinal endotoxin absorption. I. Kinetics of absorption in the isolated everted gut sac. Gastroenterol. 72:434-439.

Salehi, P., J. Walker, K. L. Madsen, G. T. Sigurdson, B. L. Strand, B. E. Christensen, L. D. Jewell, and T. A. Churchill. 2007. Relationship between energetic stress and pro-apoptotic/cytoprotective kinase mechanisms in intestinal preservation. Surgery 141:795-803.

SAS Institute Inc. 1989. SAS/STAT User's guide. SAS Institute, Cary, NC.

Schwarzenberg, S. J., and M. Bundy. 1994. Ursodeoxycholic acid modifies gut-derived endotoxemia in neonatal rats. Pediatr. Res. 35:214-217.

Silipo, A., R. Lanzetta, D. Garozzo, P. Lo Cantore, N. S. Iacobellis, A. Molinaro, M. Parrilli, and A. Evidente. 2002. Structural determination of lipid A of the lipopolysaccharide from Pseudomonas reactans. A pathogen of cultivated mushrooms. Eur. J. Biochem. 269:2498-2505.

Unno, N., M. J. Menconi, M. Smith, D. E. Aguirre, and M. P. Fink. 1997. Hyperpermeability of intestinal monolayers is induced by NO: Effect of low extracellular pH. Am. J. Physiol. 272:923-934. 